São Paulo, Brazil

rodrigo.oliandrade@gmail.com Cite this as: BMJ2020;370:m2884 http://dx.doi.org/10.1136/bmj.m2884 Published: 21 July 2020

\section{Covid-19: Prisons exposed in Brazil's crisis}

Prisons have proved fertile grounds for SARS-CoV-2 worldwide. As Latin America becomes the new epicentre of the pandemic, the unsanitary living conditions of the world's third largest prison population cannot be ignored, writes Rodrigo de Oliveira Andrade

\section{Rodrigo de Oliveira Andrade freelance journalist}

In the two months since Brazil became the country second most affected by the covid-19 pandemic, cases in its jails have soared. The country registered its first prison case in Rio de Janeiro in early March. Since then, the number of infected inmates has doubled to more than 6000 between May and July, according to Brazil's National Prison Department.

Brazil has the third largest prison population in the world-almost 750 ooo prisoners-of which 31\% are awaiting their first trial. ${ }^{1}$ As the toll increases outside so does fear among the incarcerated, who claim authorities have done too little to protect them from coronavirus. On 6 July, President Jair Bolsonaro even vetoed legislation that would have made mask use mandatory in prisons.

Ivete Maria Santos, a psychiatrist working at the Brazilian penitentiary system, says the situation will increase the risk of riots. In truth, that's already started. In early May, Puraquequara prison, in the Brazilian city of Manaus, faced riots reportedly because of fears guards could bring covid-19 into the jail. ${ }^{2}$

It was just one of a spate of disturbances across Latin America's overcrowded prisons. On 29 April, nine people were killed and dozens injured during a prison riot in Peru's capital Lima, sparked by two deaths from covid-19. ${ }^{3}$ Colombian authorities have also quashed two attempted jailbreaks linked to the coronavirus, including one that left 23 prisoners dead, while Argentina has also seen uprisings. ${ }^{4}$

In Brazil, as in other Latin American countries, prisoners are locked in damp, overcrowded, and poorly ventilated cells. Access to drinking water is limited. They also share bathrooms and living spaces, as well as personal hygiene items, such as toothbrushes and soap. Many of them are smokers, drug users, and obese with heart and respiratory illnesses, and are already at risk of infection from a variety of diseases whose transmission tends to be boosted by prisons' unsanitary conditions.

\section{In the dark}

It's estimated that about 24 ooo prisoners $-3.2 \%$ of the country's prison population-have been tested for covid-19. According to the National Prison Department, Brazil has recorded 66 covid-19 deaths in prisons, but a yet unpublished study led by Alexandra Sánchez, a physician at Oswaldo Cruz Foundation in Rio de Janeiro, suggests this number could be three times higher.

"The official data released are not trustworthy," Camila Prando, a professor at the University of
Brasília, told The BMJ. "It's not possible to know when and how they were collected, or the sort of tests used to determine the confirmed cases and deaths inside prisons," she says, adding that the numbers supplied by federal and local penitentiary administrations did not tally.

Researchers say the numbers of positive cases, although high, are still a gross underestimation given a general lack of testing capacity and the low priority of prisons. "The lack of testing makes it impossible to know the true extent of the epidemic in prisons," Gabriela Lotta, a public administration professor at Getulio Vargas Foundation in São Paulo, told The $B M J$.

Access to health services is a big problem in Brazilian jails. Half of the country's 1422 prisons don't have medical offices or rooms equipped for treating infected inmates, while those that do lack medical staff. This makes it difficult to have proper quarantine systems in place.

Without a structure for isolation in individual cells, prisoners with a suspected or confirmed diagnosis of covid-19 are put together in the same cell, says Sánchez. "Many of them go back to living among others without first being checked to see if they're still infectious."

\section{Hungry and infectious}

In early March, when the first cases started to appear across the country, the Brazilian government suspended prisoners' transfers and visits by lawyers and relatives. But this does not appear to have slowed the virus and could turn out to be counterproductive, says Rafael Godoi, a sociologist at Rio de Janeiro Federal University.

Nutrition is a major problem in Brazil's prisons. With authorities unable to feed inmates, many prisons rely on food brought in by relatives. "Prisoners' families are also primarily responsible for providing them with medicine and hygiene products," Godoi told The $B M J$. Stopping visits could affect inmates' health and hygiene, favouring the spread of other diseases, not just coronavirus.

Infectious diseases account for up to $17.5 \%$ of prison deaths in Brazil-in Rio de Janeiro, it may reach $28.5 \%$, according to Sánchez. The risk of tuberculosis infection, for example, is up to 30 times higher among prisoners than in the general population. ${ }^{5}$

"The degrading situation in Brazilian prisons is the main factor for the high rates of infectious diseases among detainees," says Sánchez. "In the same way, 
given the conditions of incarceration, each infected prisoner may transmit the coronavirus to another 10 inmates." Outside prisons, one person only infects up to three individuals on average.

Ricardo Campello, a sociologist at the University of São Paulo, says, "The only way to mitigate the transmission is to reduce overpopulation, but this has been facing resistance among judges.”

Brazil has followed countries such as China and India in discharging elderly inmates and prisoners with pre-existing conditions (such as diabetes, hypertension, and tuberculosis) jailed for nonviolent crimes. About 32500 inmates were released or sent to house arrest in the hopes that it would reduce the spread of the virus. ${ }^{6}$ It remains to be seen if this will have an effect.

\section{Spillover risk}

In the chaos of Brazil's rocketing rates of covid-19 infection and the Bolsanaro administration's ongoing denials of its seriousness, the plight of Brazil's incarcerated has gone largely unnoticed. Marcos André de Matos, a professor at the Goiás Federal University, thinks that is a mistake.

"Prisons are 'porous' institutions," he says, “The high incidence of respiratory infections among detainees may turn prisons into a source of spread for the general population.” Even though visits are suspended, prisons may amplify transmission since staff are still moving in and out of the buildings.

Almost 110 ooo Brazilians work in prisons, many of whom have not had adequate training or personal protective equipment to deal with the disease in jails, according to an ongoing study by researchers at Getulio Vargas Foundation. "Our results also suggest that more than $75 \%$ of prison officers had contact with infected prisoners," says Gabriela Lotta, who is one of the study's authors.

"The pandemic has aggravated problems that have affected Brazil's prison system for a long time," she says, "It's a powder keg about to explode."

Commissioned, not peer reviewed.

Competing interests: I have read and understood BMJ policy on declaration of interests and have no relevant interests to declare.

1 Carvalho SG, Santos ABS, Santos IM. The pandemic in prison: interventions and overisolation. Cien Saude Colet 2020:1-27.

2 Maisonnave F. Com medo do coronavírus, presos fazem reféns em motim em Manaus. 2020 www1.folha.uol.com.br/cotidiano/2020/05/com-medo-do-coronavirus-presos-fazem-refens-emmotim-em-manaus.shtml.

3 Peru jail riot: nine inmates killed after covid deaths. 2020. BBC News. www.bbc.com/news/worldlatin-america-52468293.

4 Rangel C, Daniels JP, Phillips T. “We're all on death row now”: Latin America's prisons reel from covid-19. Guardian. May 2020. www.theguardian.com/world/2020/may/16/latin-america-prisonscovid-19-riots.

5 Sánchez A, Simas L, Diuana V, Larouze B. COVID-19 in prisons: an impossible challenge for public health?Cad Saude Publica 2020;36:pmid: 32402001

6 Carneiro M, Seto G, Abbud B. CNJ fala em crescimento de $800 \%$ de casos de Covid-19 em presídios e renova recomendação para soltura. 2020. www1.folha.uol.com.br/colunas/painel/2020/06/cnj-fala-em-crescimento-de-800-de-casos-de-covid-19-em-presidios-erenova-recomendacao-para-soltura.shtml. 